Research Article

http://dx.doi.org/10.17784/mtprehabjournal.2014.12.193

\title{
Characterization of patients with COPD admitted in pulmonary rehabilitation center.
}

\author{
Caracterização de pacientes com DPOC admitidos em centro de reabilitação pulmonar.
}

João Simão de Melo Neto(1), Ana Elisa Zuliani Stroppa Marques ${ }^{(2)}$, Fabiana de Campos Gomes $^{(3)}$. Centro Universitário de São José do Rio Preto (UNIRP), São José do Rio Preto (SP), Brasil.

\begin{abstract}
Introduction: Chronic Obstructive Pulmonary Disease COPD is a major cause of morbidity and mortality, which is preventable, thus studies that discusses the characterization of a given population are important for investment in treatments and prevention. Objective: Characterize individuals with COPD, admitted to a pulmonary rehabilitation center. Method: Retrospective study, exploratory character of medical records of patients with COPD. Sample consisted of 37 patients diagnosed with COPD and age greater than 20 years. The following variables were analyzed: sex, age, marital status, occupation, diagnosis, main complaint, and cardiovascular risk factors presented by patients during admission. Results: Individuals aged $>40$ years and history of smoking have a higher prevalence in developing COPD. Pulmonary emphysema is a major pathological condition. The most common main complaint was dyspnea and cardiovascular risk factor was present sedentary lifestyle. Moreover, women with COPD were more likely to have depression than men. Conclusion: This study enabled the characterization of COPD patients, providing the possibility of investing in prevention and treatment.
\end{abstract}

Keywords: Chronic Obstructive Pulmonary Disease, Rehabilitation, Epidemiology.

\section{Resumo}

Introdução: A Doença Pulmonar Obstrutiva Crônica DPOC é uma das principais causas de morbimortalidade prevenível, assim, estudos que aborda a caracterização de uma determinada população são importantes para investimentos em tratamentos e prevenção. Objetivo: Caracterizar indivíduos com DPOC, admitidos em centro de reabilitação pulmonar. Método: Estudo retrospectivo, com caráter exploratório de prontuários de pacientes com DPOC. A amostra foi composta por 37 pacientes com diagnóstico de DPOC e idade superior a 20 anos. Foram analisadas as seguintes variáveis: sexo, idade, estado civil, profissão, diagnóstico, queixa principal, e fatores de risco cardiovasculares apresentados pelos pacientes durante a admissão. Resultados: Indivíduos com $>40$ anos e histórico de tabagismo apresentam maior prevalência em desenvolver DPOC, e o enfisema pulmonar foi a principal condição patológica. A queixa principal mais frequente foi dispneia e o fator de risco cardiovascular mais apresentado foi o sedentarismo. Além disso, muIheres com DPOC apresentaram mais chance de terem depressão que homens. Conclusão: Este estudo possibilitou a caracterização de pacientes com DPOC, proporcionando a possibilidade de investimento em prevenção e tratamento.

Palavras-chave: Doença Pulmonar Obstrutiva Crônica, Reabilitação, Epidemiologia.

Received: 4 June 2014. Accepted: 2 September 2014. Published: 12 September 2014.

1. Master in Saúde e Envelhecimento, Faculdade de Medicina de Marília (FAMEMA), Marília (SP), Brazil.

2. Doctor student in Desenvolvimento Humano e Tecnologias, Universidade Estadual Paulista (UNESP), Rio Claro (SP), Brazil.

3. Master in Biologia Geral e Aplicada. Universidade Estadual Paulista (UNESP), Botucatu (SP), Brazil. 


\section{INTRODUCTION}

Chronic obstructive pulmonary disease (COPD) is characterized by being progressive and persistent, including a number of respiratory disorders that generate losses in functional capacity and respiratory. ${ }^{(1,2)}$ The occurrence of COPD can be contained with the identification of the population at high risk and consequently initiate early treatment to slow the progression of the disease. ${ }^{(3)}$ In addition, late diagnosis and treatment of disease may limit and result in poorer clinical outcome. (2)

COPD is a major cause of preventable morbidity and mortality worldwide ${ }^{(4)}$ is still underdiagnosed in Brazil. ${ }^{(5)}$ In addition, epidemiological data related to the disease are scarce. ${ }^{(5)}$ Within this context, studies on the characterization of a given population are important and fundamental as information relevant to prove that national guidelines be developed or re-evaluated to meet the particular characteristics of a given population. ${ }^{(6)}$

Thus, this study aims to characterize individuals with Chronic Obstructive Pulmonary Disease, admitted to a pulmonary rehabilitation.

\section{METHODS}

Retrospective and not randomized study, exploratory nature of patients's records with COPD. The sample consisted of 37 patients admitted for pulmonary rehabilitation in Fisioterapia Cardiorrespiratória department of a medical school in the city of São José do Rio Preto. Patients diagnosed with COPD and age over 20 years were included in the survey. Patients with incomplete medical records were excluded.

The following variables were analyzed: gender, age, marital status, occupation, diagnosis, main complaint, and cardiovascular risk factors presented by patients, among these: hypertension (HBP), diabetes mellitus (DM), accentuation of body weight (overweight and obesity), physical inactivity (no regular physical activity), alcohol consumption (historical constant alcohol intake reported by the patient), depression (using drugs) and smoking ("yes", "no", "passive" and "former smoker").

For data analysis we used descriptive and inferential statistics. Descriptive results were expressed as mean, standard deviation $( \pm)$, absolute and relative frequencies. Tests were used: unpaired t test, Welch corrected, to compare age between men and women and to verify the similarity between the groups; and odds ratio (OR) between the variables with Chi-square test. Was considered as $p \leq 0.05$ level of significance. Statistical analysis was performed using Instat program (version 3.0, GraphPad, Inc., San Diego, CA, USA).

This study was approved by the Ethics Committee in Research of the Instituto de Moléstias Cardiovasculares - IMC/SP, under the Protocol number. 015.08.010. Data were cataloged with only registration code, to preserve the confidentiality and privacy of patients.

\section{RESULTS}

The sample consisted of 37 patients ( $57 \%$ women) with a mean of $65.81 \pm 15.53$ years old. There was no significant difference $(p=0.08)$ between the mean ages of the women (62.14 \pm 18.36 years) and men (70.62 \pm 9.26 years), demonstrating similarities between samples. Compared to patients admitted for pulmonary rehabilitation, the main features were: age $>40$ years; $51 \%$ in a stable relationship; and $46 \%$ retired (Table 1 ).

Subjects had a diagnosis of bronchial asthma (32\%) and pulmonary emphysema (68\%). The most common main complaint was shortness of breath in $76 \%$ of patients, 19 had only one complaint, 17 had two and the other three, totaling 56 main complaints (Table 1 ). The cardiovascular risk factors reported by patients were more sedentary lifestyle $(81 \%)$, history of smoking (68\%) and hypertension (38\%) (Table 2). Regarding to patients with a history of smoking, about $24 \%$ were active smokers, $8 \%$ passive and $68 \%$ former smokers (Table 2).

During data analysis, we found that: women with COPD were more likely to have depression than men (OR: 6.00, p = 0.043); women with a history of smoking are more likely to develop COPD compared to men (OR: $3.25, p=0.060)$; and the history of smoking increases the chances of having pulmonary emphysema in relation to chronic bronchitis (OR: 22.00, p = 0.0003).

\section{DISCUSSION}

COPD diagnosed in the Brazilian population is the fifth leading cause of morbidity and mortality, and the number of deaths has increased in the last twenty years in subjects of both gender. This situation is worrisome, especially because this disease can be preventable, such as by investing in campaigns against smoking. (7) Epidemiological studies may assist in the identification, prevention and early treatment of patients with COPD.

In the present study, we observed higher prevalence of COPD in patients > 40 years and history of smoking (68\%). According Sandelowsky et al. ${ }^{(8)}$ these individuals are more likely to develop this disease, especially when the clinical condition is associated with any kind of respiratory infection, being essential to identify these high-risk groups, aiming to motivate these patients to stop smoking.

We also observed that among COPD is the most common diagnosis of pulmonary emphysema. Stu$\operatorname{dies}^{(7,9)}$ have reported that there is a higher ratio pulmonary emphysema and cancer that individuals with chronic bronchitis. Moreover, the history of smoking increased the odds of having emphysema in relation to chronic bronchitis. Smoking is the main responsible for the majority of diagnosed cases of pulmonary emphysema. ${ }^{(10)}$

The framework of obstruction in patients with COPD 
is progressive and is directly related to an abnormal inflammatory process resulting from increased inflammatory markers such as TNF-a and interleukins, caused especially by inhalation of toxic particles or gases, and smoking the main identified cause. ${ }^{(7)}$

In this study, the most common main complaint was dyspnea and cardiovascular risk factor was presented more sedentary. Dyspnea is progressive, per- sistent and triggered by losses in the biomechanics of the thoracic diaphragm provided hyperinflation, resulting in an increased work of breathing even stopped.(11) In order to avoid this disabling symptom, these individuals become more inactive, accentuating the level of inactivity, entering a vicious cycle of isolation from society, thus worsening dyspnea and depression. ${ }^{(11)}$

Table 2. Cardiovascular risk factors present in patients, according to gender.

\begin{tabular}{lccc}
\hline & Women $(\mathbf{n = 2 1})$ & Men $(\mathbf{n = 1 6 )}$ & Total $(\mathbf{n = 3 7 )}$ \\
\hline Hypertension & $06(29 \%)$ & $08(50 \%)$ & $14(38 \%)$ \\
Diabetes & $03(14 \%)$ & $02(13 \%)$ & $05(13 \%)$ \\
Increased body weight & $01(5 \%)$ & - & $01(3 \%)$ \\
Sedentary & $16(76 \%)$ & $14(88 \%)$ & $30(81 \%)$ \\
Alcoholism & $03(14 \%)$ & $05(31 \%)$ & $08(22 \%)$ \\
Depression & $06(29 \%)$ & $01(6 \%)$ & $07(19 \%)$ \\
History of smoking & $12(57 \%)$ & $13(81 \%)$ & $25(67 \%)$ \\
Active & $04(19 \%)$ & $02(13 \%)$ & $06(16 \%)$ \\
Passive & $02(10 \%)$ & - & $02(5 \%)$ \\
Former smoker & $06(29 \%)$ & $11(69 \%)$ & $17(46 \%)$
\end{tabular}

Table 1. Distribution of patients by age, marital status, occupation and main complaint, according to gender.(a) Jobs with a sample of just one individual.

\begin{tabular}{|c|c|c|c|}
\hline Age & Women $(n=21)$ & $\operatorname{Men}(n=16)$ & Total $(n=37)$ \\
\hline $21-40$ years & $02(10 \%)$ & - & $02(6,0 \%)$ \\
\hline $41-60$ years & $08(38 \%)$ & $02(12 \%)$ & $10(27 \%)$ \\
\hline $61-80$ years & $08(38 \%)$ & $12(76 \%)$ & $20(54 \%)$ \\
\hline$>81$ years & 03 (14\%) & $02(12 \%)$ & 05 (13\%) \\
\hline \multicolumn{4}{|l|}{ Marital Status } \\
\hline Single & $05(24 \%)$ & $01(6 \%)$ & $07(19 \%)$ \\
\hline Stable union & $08(38 \%)$ & $11(69 \%)$ & $19(51 \%)$ \\
\hline Divorced & $02(9 \%)$ & $03(19 \%)$ & $05(12 \%)$ \\
\hline Widowed & $06(29 \%)$ & $01(6 \%)$ & $07(18 \%)$ \\
\hline \multicolumn{4}{|l|}{ Occupation } \\
\hline Retired & $08(38 \%)$ & $09(56 \%)$ & $17(46 \%)$ \\
\hline Home & $07(33 \%)$ & - & $07(19 \%)$ \\
\hline Businessman & $01(5 \%)$ & $02(13 \%)$ & $03(8 \%)$ \\
\hline Secretary & $02(10 \%)$ & - & $02(5,0 \%)$ \\
\hline Other (a) & $03(14 \%)$ & $05(31 \%)$ & $08(22 \%)$ \\
\hline Main complaint & $n=28$ & $n=24$ & $n=56$ \\
\hline Tiredness & $02(7 \%)$ & $04(17 \%)$ & $06(11 \%)$ \\
\hline Difficulty in walking & $01(3 \%)$ & $01(4 \%)$ & $02(4 \%)$ \\
\hline Pain & $07(25 \%)$ & $03(13 \%)$ & $10(18 \%)$ \\
\hline Breathlessness & $15(55 \%)$ & $13(54 \%)$ & $28(50 \%)$ \\
\hline Lack of appetite & $02(7 \%)$ & - & $02(4 \%)$ \\
\hline Weakness & $01(3 \%)$ & $01(4 \%)$ & $02(4 \%)$ \\
\hline Cough & - & $02(8 \%)$ & $02(4 \%)$ \\
\hline
\end{tabular}


Within this context, women with COPD were more likely to have depression than men. The literature ${ }^{(12-15)}$ demonstrates that depressive disorders are more prevalent in women than men with COPD. Studies(12,16) reported that depressive symptoms in these patients result in reduced quality of life, greater retention and readmissions in the hospital environment and increased mortality.

\section{CONCLUSION}

Thus, we conclude that patients over than 40 years and history of smoking have a higher prevalence of developing COPD and that emphysema was the primary pathological condition. The most common main complaint was dyspnea and cardiovascular risk factor was presented more sedentary. In addition, women with COPD were more likely to have depression than men.

\section{REFERENCES}

1. Rochester CL, Fairburn C, Crouch RH. Pulmonary Rehabilitation for Respiratory Disorders Other than Chronic Obstructive Pulmonary Disease. Clin Chest Med. 2014; 35(2): 369-389.

2. Estes TS, Short N, Bowser D, Boyle A. An evidence-based quality improvement perspective for a chronic obstructive pulmonary disease case-finding program. Chron Respir Dis. 2014 [Epub ahead of print].

3. Kotz D, Nelemans P, van Schayck CP, Wesseling GJ. External validation of a COPD diagnostic questionnaire. Eur Respir J. 2008; 31(2): 298-303.

4. Lopez AD, Shibuya K, Rao C, Mathers CD, Hansell AL, Held LS, et al. Chronic obstructive pulmonary disease: current burden and future projections. Eur Respir J. 2006; 27(2): 397-412.

5. Francisco PMSB, Donalisio MR, Barros MBA, César CLG, Carandina L, Goldbaum M. Factors associated with pulmonary disease among the elderly. Revista de Saúde Pública. 2006; 40(3): 428-435.

6. de Melo Neto JS, Mendes AP, Aragao I, Alves AS, Correa PR, Romano EM. Perfil dos Pacientes Atendidos no Setor de Fisioterapia Cardiorrespiratório de uma Clínica Escola de São José do Rio Preto - SP. Arquivos de Ciências da Saúde (FAMERP) 2012; 19: 108-112.

7. Laizo A. Doença pulmonar obstrutiva crónica: Uma revisão. Rev Port Pneumol. 2009; 15(6): 1157-1166.

8. Sandelowsky H, Ställberg B, Nager A, Hasselström J. The prevalence of undiagnosed chronic obstructive pulmonary disease in a primary care population with respiratory tract infections - a case finding study. BMC Fam Pract. $2011 ; 12: 122$.

9. Turner MC, Chen Y, Krewski D, Calle EE, Thun MJ. Chronic obstructive pulmonary disease is associated with lung cancer mortality in a prospective study of never smokers. Am J Respir Crit Care Med. 2007; 176(3): 285-290.

10. Silva DR, Gazzana MB, Barreto SSM, Knorst MM. Idiopathic pulmonary fibrosis and emphysema in smokers. Jornal Brasileiro de Pneumologia 2008; 34(10): 779-786.

11. Moreno J, Dal Corso S, Malaguti C. Análise descritiva do uso de ventilação mecânica não invasiva durante exercício em paciente com DPOC. Conscientiae Saúde 2007; 6(2): 295-303.

12. Jennings $\mathrm{JH}$, Digiovine $B$, Obeid D, Frank $C$. The association between depressive symptoms and acute exacerbations of COPD. Lung 2009; 187(2): 128-135.

13. Laurin C, Lavoie KL, Bacon SL, Dupuis G, Lacoste G, Cartier A, et al. Sex differences in the prevalence of psychiatric disorders and psychological distress in patients with COPD. Chest 2007; 132: 148-155.

14. Martinez FJ, Curtis JL, Sciurba F, Mumford J, Giardino ND, Weinmann G, et al. Sex differences in severe pulmonary emphysema. Am J Respir Crit Care Med. 2007; 176: 243-252.

15. Chavannes NH, Huibers MJ, Schermer TR, Hendriks A, van Weel C, Wouters EF, et al. Associations of depressive symptoms with gender, body mass index and dyspnea in primary care COPD patients. Fam Pract. 2005; 22: 604607.

16. da Costa CC, de Azeredo Lermen C, Colombo C, Canterle DB, Machado ML, Kessler A, et al. Effect of a Pulmonary Rehabilitation Program on the levels of anxiety and depression and on the quality of life of patients with chronic obstructive pulmonary disease. Rev Port Pneumol. 2014 [Epub ahead of print]. 